\title{
Economic Sustainability Analysis of Halal Tourism Development in Banyuwangi Regency
}

\author{
Dini Nafisatul Mutmainah'); Muksin'2); Sri Sundari²) \\ 1)Study Program of Agribusiness Magister, Politeknik Negeri Jember \\ 2)Major of Agribusiness Management, Politeknik Negeri Jember \\ Email: ${ }^{1)}$ dini.nafisatul96@gmail.com; ${ }^{2)}$ muksin.alyasini@gmail.com; \\ ${ }^{2)}$ sundari.tugasmhs1@gmail.com
}

\section{How to Cite :}

Mutmainah, D.N., Muksin, Sundari, S. 2020. Analysis of the Sustainability of the Economic Dimension to the Development of Halal Tourism in Banyuwangi Regency. Journal of Agri Socio-Economics and Business. 1 (1): 15-22. DOI: https://doi.org/10.31186/jaseb.2.1.15-22.

\section{ARTICLE HISTORY \\ Received [23 May 2020] \\ Revised [27 May 2020] \\ Accepted [11 June 2020] \\ KEYWORDS \\ Halal Tourism, \\ Economic Dimension, \\ Multi Dimensional \\ Scalling (MDS).}

This is an open access article under the $C C-B Y-S A$ license

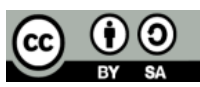

\section{ABSTRACT}

Halal tourism is a tour that implements Islamic laws in it, which aims to meet tourists needs. The purpose of this paper is to identify a sustainability status, formulate sustainable development models and scenarios, and design a strategy or policy development halal tourism sustainability in Regency of Banyuwangi. This paper uses a combination of quantitative and qualitative approaches (mixed method). The analytical tool used in this paper is the Multi Dimensional Scaling Analysis (MDS) to identify the condition of the status of halal tourism sustainability. Data are obtained through observation, surveys, expert interviews, and documentation. The results of this study indicate that the economic dimension is the most influential dimension on the sustainability of halal tourism in Banyuwangi Regency. MDS analysis, in the economic dimension there are 5 priority lever factors that affect the economic dimension and it is very important to consider among them, 1) the priority of the first attribute is Tourism Marketing Access with 2.73; 2) the second priority attribute is the Absorption of Labor with the value $2.68 ; 3)$ the third priority attribute is the Tourism Land Status with the attribute effect value of 2.41 ; 4) the fourth priority attribute is the Area of Tourism Land Mastery with the value of the influence of the attribute of 1.95; and 5) the fifth priority attribute, the Cost of Tourism Management with the value of 1.83.. 


\section{INTRODUCTION}

The tourism sector is a sector that has quite promising opportunities, because aside from being one of the producers of tourism economic growth. One of the tourism sectors in Indonesia is marine tourism. Marine tourism is one of the most important things in Indonesia. Indonesia's larger territory is dominated by this sea area, indeed it is very attractive to many tourists. Tourism has also developed into a global phenomenon which is a basic need, as well as a part of human rights that must be respected and protected. The Government and Local Government, the tourism business world, and the community are obliged to ensure that travel as a right of everyone can be upheld (UU No.10, 2009).

One of the most popular tourism by the public and abroad is halal tourism, especially halal tourism in Indonesia which is currently growing. This is because Indonesia is a country with the largest Muslim population in the world. Some time ago, Indonesia won the top position in the 2019 Mastercard-Crescent Rating "Global Muslim Travel Index" (GMTI). Fazal Bahardeen as the CEO of Crescent Rating and Halal Trip stated that after previously 2018 was ranked second, in 2019 Indonesia occupies the first position in GMTI along with Malaysia with a score of 78 (quoted from Kompas.com 2019). The Minister of Tourism, Mr. Arief Yahya, also appreciated the Mastercard-Crescent "Global Muslim Travel Index" which gave the highest rating in Indonesia.

Halal tourism itself continues to experience rapid growth, some of the drivers of growth are the Muslim population that forms a religious group, the growth of the middle class in countries with a majority Muslim population (such as Indonesia and Malaysia), and the growth of Muslim millennials that can shape the future of halal tourism . In addition to developing halal tourism, the Indonesian government has also made cooperation with countries joined in the Organization of the Islamic Conference (OIC) for promotion. Promotion is also carried out by Indonesia by participating in the World Halal Travel Award (quoted wartaekonomi.co.id, 2019).

Coinciding with Indonesia, which has been able to reach the top position in the Mastercard-Crescent Rating Index "Global Muslim Travel Index" (GMTI) in 2019, Indonesia re-introduced its new halal tour, namely halal tourism, Santen Island, Sharia Coast which is located right in Karangrejo Village, Banyuwangi Regency East Java. Banyuwangi is also one of the favorite tourist destinations in East Java. Santen Island Sharia Coast is the first halal/sharia concept beach tourism in Banyuwangi, even in East Java. This halal/sharia label contains Islamic meaning especially for Muslim communities. The concept of halal/sharia tourism is tourism that implements Islamic laws in it. The application of the concept of halal/sharia in halal tourism in Banyuwangi aims to meet the need of tourists, especially women. So in this halal tourism female and male visitors are separated.

The sharia coast was originated by the Banyuwangi Regent, Mr. H. Abdullah Azwar Anas. This idea departed from the condition that the majority of the Indonesian population are Muslim. Therefore, this idea will create a very big 
opportunity and has the potential to increase the citizen economy. Based on the economic growth of Banyuwangi Regency, the halal tourism of Santen Island Sharia Coast which has existed since the beginning of 2017 has yet to show its development. Based on innitial survey and interview results, after two years experiences legitimate travels either for visitors or tourist facilities halal have declined (Department of Culture and Tourism District Banyuwangi, 2019).

Facilities in the form of a number of seats and umbrellas provided by the Banyuwangi Regency's Office of Culture and Tourism are now being withdrawn. These due to the lack of care from all members of the Tourism Awareness Group in caring for the facility. Not only those facilities, wind chairs provided for halal tourism in Santen Island Syariah Beach a year ago, have not been utilized anymore by the manager as one of the attractions for tourists. In this case the sustainability development strategies are looked for realizing halal tourism development. For this reason, the community around the halal tourism of Santen Island Sharia Coast who are aware of the environment, both from the government, private sector, and the village community are expected to help and support the successful development of halal tourism in the Santen Coast Syariah. The purpose this reseach are 1) To identify the condition of sustainability halal tourism, 2) To formulate the model and the scenario of the sustainability development of halal tourism in Banyuwagi, and 3) To determine the attribute priority on the economy dimension.

\section{RESEARCH METHODS}

\section{Method of Collecting Data}

The research location was determined purposively, namely in the halal tourism of Santen Island Syariah Beach, In Karangrejo Village, Karanganom Environment, Banyuwangi Regency. This research was conducted in January to May 2020.

This research used a qualitative and quantitative approach, the qualitative method aims to explain the real condition of research objects, and clarify research data, while the quantitative methods used to examine the population and certain samples, collecting data using research instruments, as well as statistical data analysis (Sugiyono, 2016).

The sample in this study used a purposive sampling technique, whereby the respondent (expert) was deliberately determined by the researcher. This technique is a sampling technique with special consideration, so it is appropriate to be a respondent (expert) (Noor, 2011). Samples in this study include, the Head of the Development and Management of Tourism Destinations in the Culture and Tourism Office of Banyuwangi Regency, the Chairperson of the Tourism Awareness Group in the halal tourism of Pulau Santen Pantai Syariah, and Academics who comprehend about tourism in Banyuwangi. 


\section{Data Analysis Method}

Multi-dimensional scalling (MDS) associated with the manufacture of the folder to describe the position of an object with another object based on the similarity of these objects (Susanto, 2012). Each attribute on each dimension is given a score based on scientific judgment from the score maker. The range of scores ranges from 1-3, or depends on the state of each attribute interpreted starting from bad (1) to good (3). Value score of each attribute analyzed multidimensional to specify one or several points that reflect the position of the sustainability of halal tourism development were examined relative to two reference points, which is a good point (good) and the bad points (bad) (Kholil, 2015). There are some attribute of the economy dimension in this research, 1) ticket price, 2) the amount of labor, 3) the large of the tourism object authority, 4) the properly of the tourism object, 5) citizen's income perkapita, 6) area income, 7) the labor absorption, 8) the management of the tourism object, 9) the mechanism of sharing profit, 10) areal status, 11) the acces of tourism marketplace, 12) marketplace range, 13) government assistance, and 14) the development of the local product based on local raw material.

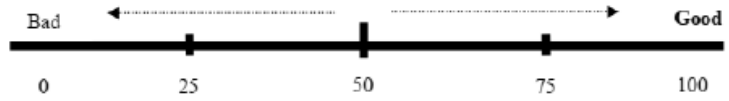

Figure 1 .

Bad and Good Reference Points (Fauzi dan Anna, 2005).

Furthermore, Ordination Analysis through the MDS method, namely the position of the point of sustainability, can be visualized through the horizontal and vertical axis. With the rotation process, the position of the point can be visualized on the horizontal axis with a sustainability index value of $0 \%$ (bad) and $100 \%$ (good). If the system studied has a sustainability index value greater or equal to $50 \%$ (> 50\%), then the system is said to be sustainable, and is said to be unsustainable if the index value is less than $50 \%(<50 \%)$ (Bakeri, 2012). The sustainability index value uses a scale developed by Columbia Canada University, as presented in Table 1.

Table 1 . Sustainability Status Category

\begin{tabular}{ll}
\hline \multicolumn{1}{c}{ Index Value } & \multicolumn{1}{c}{ Category } \\
\hline $0.00-25.00$ & Bad (not sustainable) \\
$25.01-50.00$ & Less (less sustainable) \\
$50.01-75.00$ & Sufficient (quite sustainable) \\
$75.01-100.00$ & Good (very sustainable) \\
\hline
\end{tabular}

Source : Fauzi dan Anna, 2005.

Identification of the potential for halal tourism sustainability in Banyuwangi was analysed using the Interpretative Structural Modeling (ISM) method, the first step taken by determining the sub-elements in the potential element of halal tourism 
sustainability (Nahar, 2016). The selection of sub-elements of the potential for halal tourism sustainability is carried out by literature study and expert survey.

\section{RESULTS AND DISCUSSION}

Analysis of tourism sustainability in Banyuwangi Regency is conducted to find out the status of halal tourism sustainability, especially in halal tourism in Santen Island Sharia Coast in Karangrejo Village, Banyuwangi Regency. The sustainability analysis can be seen from various dimensions of sustainability, as well as the formulation of a development strategy for the sustainability of tourism in Banyuwangi based on the sustainability analysis that has been done previously.

Sustainability of halal tourism in Banyuwangi viewed from the economic dimension can be seen in the following Figure 2. Viewing from the economic dimension based on Figure 2, halal tourism in Banyuwangi Regency is categorized as Sustainable Enough with a value of 70,70 .

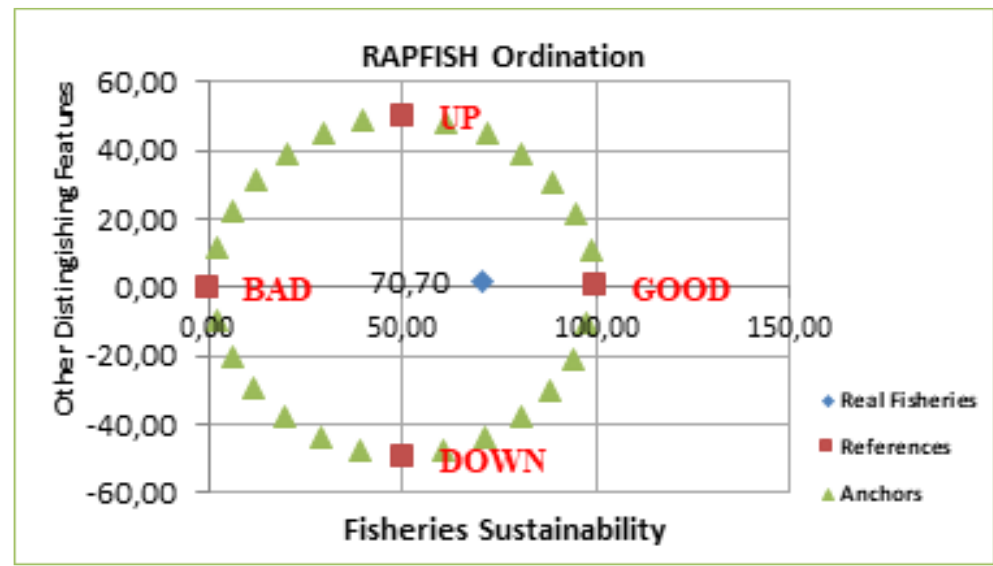

Figure 2.

Sustainability Status Based on Economic Dimensions.

The influence of each attribute on the economic dimension on the sustainability of halal tourism in Banyuwangi can be seen in Figure 3. Based on this figure, there are 5 priority factors that affect the economic dimension and they are very important, 1) the first attribute priority is the Tourism Marketing Access with value $2.73 ; 2$ ) the second priority attribute is the Absorption of Labor with the value $2.68 ; 3)$ the third priority attribute is the Tourism Land Status with value 2.41 ; 4) the fourth priority attribute is the Area of Tourism Land Mastery with the value of the influence of the attribute of 1.95; and 5) the fifth priority attribute, the Cost of Tourism Management with the value 1.83. 


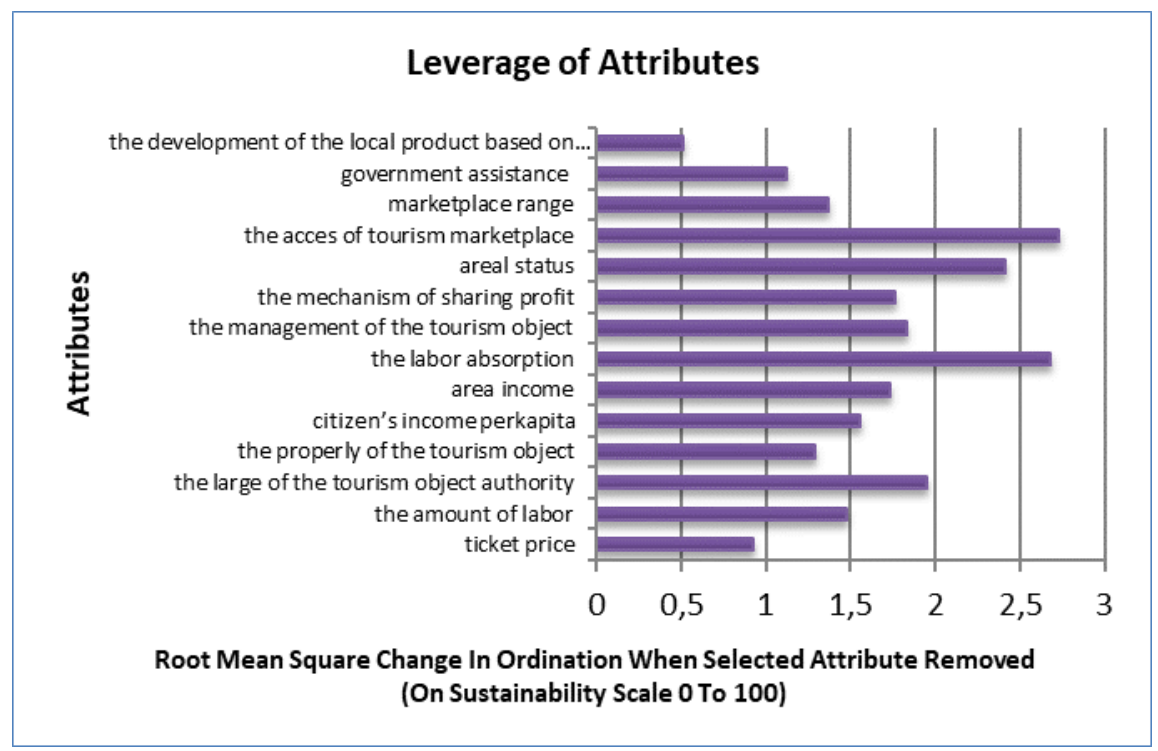

Figure 3.

Effect of Attributes on Economic Dimensions.

The marketing of halal tourism in Santen Pantai Syariah Beach is still carried out by the Banyuwangi Regency Government, through websites, mass media, print media, and social media. This happens because the management of halal tourism is still very less independent. All tourism marketing tasks are totally dependent on the Government. In this case, it is necessary to make continued communication and cooperation between halal tourism managers and the Banyuwangi Regency Government especially the Banyuwangi Regency Culture and Tourism Office. The factor of leveraging access for tourism suppliers is aimed at making it easier for tourists to access some of the tours in Banyuwangi, especially halal tourism in Santen Island, Syariah Beach. So halal tourism in Banyuwangi will be better well known by domestic and even foreign tourists.

When the halal tourism of Banyuwangi is known by all levels of society, then the second lever factor, the absorption of Labor will follow. Where local people can try to earn extra income outside their main job as fishermen, by working in halal tourism, for example as parking guards, ticket ticket guards, opening stalls to sell everything from snacks until the special dishes of halal tourism that is seafood. Local people can also use the empty rooms in their homes for rent as lodging in halal tourism for tourists who want to spend the night, of course still by implementing Islamic law in them. Even Santen Island Student Group (PEPUSAN) can also sell their handicrafts on halal tourism as a part of their hard work.

Halal tourism in the Regency of Banyuwangi is a tour that was deliberately triggered by the Regent of Banyuwangi Regency to expand its market reach in the tourism sector. This halal tourism is located in the center of the city of Banyuwangi whose land status is still owned by the Army, therefore the halal tourism revenue must also be shared equally with details, namely $20 \%$ for the Army, $10 \%$ for Local 
Government, and 70\% for halal tourism (Banyuwangi Regency Culture and Tourism Office, 2020). Overall, the total area of halal tourism in Banyuwangi is \pm 4 hectares. However, with the quite extensive land tenure, the manager still has not used it to its full potential. There is a need for sustainable development in order to maximize the results of halal tourism development in Banyuwangi Regency.

The last factor or as the fifth priority, the Tourism Management Costs are entirely obtained from the Banyuwangi Regency Government. Other social assistance in the form of a beach clean activity program that has been carried out in halal tourism comes from organizations or groups of mothers and teenage children around Banyuwangi. The management costs referred to in the development of halal tourism from the Banyuwangi Regency Government so far have been in the form of foam chairs and beach umbrellas, wind chairs, construction of Counseling Centers, Rantang program where each resident's house is given one rice basket to be eaten as a family, training and counseling for tourism, empowerment the community, a beach clean program by making chairs filled with beach trash, a youth halal tourism development program in the activity of making handicrafts from shells, as well as developing processed products made from community-based local potential in halal tourism.

But so far, some of the programs that have been held in halal tourism have not been run optimally by the local community. So that the community still can get the maximal results. There is a big hope from the author for halal tourism in Banyuwangi Regency, because halal tourism is one of the world's candelas which can be used as a weapon by Indonesia in spreading its wings abroad to improve the country's economy.

\section{CONCLUSIONS AND POLICY IMPLICATIONS}

\section{Conclusions}

MDS analysis, in the economic dimension there are 5 priority lever factors that affect the economic dimension and it is very important to consider among them, 1) the priority of the first attribute is Tourism Marketing Access with 2.73; 2) the second priority attribute is the Absorption of Labor with the value 2.68 ; 3) the third priority attribute is the Tourism Land Status with the attribute effect value of 2.41 ; 4) the fourth priority attribute is the Area of Tourism Land Mastery with the value of the influence of the attribute of 1.95; and 5) the fifth priority attribute, the Cost of Tourism Management with the value of 1.83 .

\section{Recommendations}

Based on the analysis that has been described, the authors recommend to maintain the existing Banyuwangi District Government programs, both in the form of counseling, training, empowerment, and social assistance in accordance with applicable regulations. So that it can be pursued to make halal tourism in 
Banyuwangi Regency become more developed and efficient for the local community. Likewise with its existence as a tourist destination for all levels of tourists, especially foreign tourists. It is hoped that by maintaining and optimizing the Banyuwangi Regency Government programs, the halal tourism of Santen Island Syariah Beach will be even more developed and included in the list of one of the favorite tourist attractions.

\section{REFERENCES}

Aryanto, A. 2019. Portal Berita Ekonomi : Ranking 5 Negara Tujuan Wisata Halal di Indonesia. Diakses tanggal 12 Februari 2020. Tersedia pada : https://www.wartaekonomi.co.id/read183288/inilah-ranking-5-negaratujuan-wisata-halal-indonesia.

Bakeri, S., et.al. 2012. Analisis MDS (Multi Dimensional Scalling) untuk Keberlanjutan Pengelolaan Air Lintas Wilayah Studi Kasus DKI Jakarta. Jurnal Teknik Lingkungan. 13(1): 13-23.

Dinas Kebudayaan dan Pariwisata Kabupaten Banyuwangi. 2020. Wisata Halal Pulau Santen Pantai Syariah.

Fauzi, A dan Anna, S. 2017. Tantangan Pengembangan Wisata Halal di Nusa Tenggara Barat. Jurnal Aspirasi. 8(1): 65-80.

Firmansyah. 2016. Model Pengendalian Konservasi Lahan Sawah di dalam DAS Citarum. Institut Pertanian Bogor: Disertasi.

Kholil, A.D Tony, dan W. Ani. 2015. Pendekatan Multi Dimensional Scalling untuk Evaluasi Keberanjutan Waduk Cirata-Provinsi Jawa Barat. Jurnal Manusia dan Lingkungan. 22(1): 22-31.

Nahar, Julita. 2016. Penerapan Metode Multi Dimensional Scallig dalam Pemerataan Sarana Kesehatan di Jawa Barat. Bandung : Jurnal Volume 12 No. 1 ISSN 1412-6184.

Noor, J. 2011. Metodologi Penelitian. Jakarta: Kencana.

Sugiyono. 2016. Metode Penelitian Kuantitatif, Kualitatif, dan R \& D. Bandung: Alfabeta.

Susanto A., Rusdiyanto, E., dan Sumartono. 2012. Analisis Keberlanjutan Pemanfaatan Situ Kedaung, Kecamatan Pamulang Kota Tangerang Selatan. Laporan Penelitian Lanjut Bidang Ilmu. Hal. 1-56.

Undang-undang Republik Indonesia. 1990. Undang-undang Republik Indonesia Nomor 09 Tahun 1990 Tentang Kepariwisataan. www.hukumonline.com. Diakses 12 Maret 2020.

Wisataperadaban.com, Studipariwisata.com, https://disbupar.acehprov.go.id, Kompas, AntaraNews. Diakses 2020 Januari 22; Tersedia pada : https://www.goodnewsfromindonesia.id/2019/04/13/wisata-halal-apa-sihartinya. 